\title{
Espaço urbano e segregação socioespacial: uma análise da representação da violência na mídia impressa em Campos dos Goytacazes
}

\author{
Nágila da Silva Ferreira Souza ${ }^{1}$ \\ Silvana Cristina da Silva²
}

O medo da violência criminosa tem se tornado frequente entre os citadinos, seja pelo aumento da violência real, seja em razão do aumento da sensação da violência criminosa, no qual o discurso midiático tem grande responsabilidade. Nesse sentido, buscamos analisar a representação da violência em Campos dos Goytacazes e a relação desse discurso com a expansão dos condomínios residenciais fechados, especialmente para as elites e para a classe média. A difusão desses residenciais na cidade conecta-se ao medo do aumento da violência criminosa. A análise apontou que o discurso midiático é um componente da segregação ao classificar e estigmatizar bairros e regiões da cidade como violentos. Assim, a violência representada pela mídia impressa porta uma dimensão simbólica da segregação do espaço urbano, ou seja, parte da cidade é segregada por não receber adequadamente políticas públicas, mas também pelos discursos de estigmatização de bairros.

Palavras-chave: Espaço Urbano, Segregação, Campos dos Goytacazes, Violência Urbana.

\section{Urban space and segregation: an analysis of the representation of violence and violence representation in Campos dos Goytacazes}

The fear of criminal violence has become frequent amongst citizens, whether because real violence increasing or due to the increasing of criminal violence sensation, in which media discourse has great responsibility. In that sense, we aim to analyze the representation of violence in Campos dos Goytacazes and its relation with the expansion of closed residential condominiums, especially for the elite and middle class members. The diffusion of these residential areas in town can be connected to the fear of the criminal violence growth. The analysis showed that media discourse is a component of segregation when classifies and stigmatizes neighbourhoods and city areas as violent. That way, violence represented by pressed media carries a symbolical dimension of the segregation of urban space, which means that part of the city is separated for not receiving proper public politics, and also for the neighbourhood stigmatisation discourse.

Keywords: Urban Space, Segregation, Campos dos Goytacazes, Urban Violence.

\footnotetext{
${ }^{1}$ Graduada em Geografia. Universidade Federal Flumininse. nagela_sf@hotmail.com

${ }^{2}$ Professora da Universidade Federal Fluminense (UFF-Campos). silvanasilva@id.uff.br
} 


\section{INTRODUÇÃO}

Neste artigo, buscamos analisar a relação entre a representação da violência e a estigmatização de bairros em Campos dos Goytacazes, estigmatização essa que vem contribuindo com a expansão dos condomínios residenciais fechados. Para esta pesquisa, foram realizados alguns procedimentos metodológicos como levantamento bibliográfico sobre o tema; pesquisa de dados secundários no Instituto de Segurança Pública do Estado do Rio de Janeiro (série histórica 2003 a 2015); e entrevistas com agentes de segurança pública, especificamente com o delegado da delegacia de polícia da $146^{a}$ DP (localizada no subdistrito Guarus). Foram também realizados levantamentos de dados sobre alguns crimes, como estupros, roubos a transeuntes e a residências e homicídios nos jornais "O Diário" e a "Folha da Manhã", dois jornais locais de grande circulação. Após os levantamentos dos dados, foram feitos gráficos, tabelas e mapas para auxiliar as análises.

Partimos da conceituação de Corrêa (2005, p. 7), que define espaço urbano como resultado dos diferentes usos do solo. Esses usos consistem na organização espacial da cidade, que se apresenta fragmentada. São áreas distintas em forma e em conteúdo social. O espaço urbano é fragmentado pela justaposição de usos, pelos diferentes agentes. Tanto o espaço urbano quanto os agentes são passíveis a mudança no processo histórico. Ele é articulado pela existência de fluxos de pessoas, mercadorias, informações, decisões. É reflexo da sociedade, pois revela a estrutura social, vista através das classes sociais, e é onde se observa segregação e desigualdade. É um condicionante social, isso porque as formas espaciais condicionam as práticas sociais. É um espaço simbólico que contém valores, mitos, crenças e é campo de lutas, já que existem no espaço urbano conflitos, falta de cidadania e desníveis de renda, gerando movimentos sociais urbanos.

Para Correa (2013, p. 43), a divisão social em classes reflete na paisagem urbana. As populações com alto poder aquisitivo vão habitar áreas mais valorizadas, bem como a própria estrutura da residência será de melhor qualidade; já a população menos abastada tenderá a habitar áreas menos valorizadas, assim como suas residências não serão bem estruturadas, tanto no aspecto estéticoarquitetônico quanto no acesso à infraestrutura. Esse processo é chamado de segregação residencial, o que explica a concentração de população em um dado território do espaço urbano, como uma apropriação desigual do espaço. Ela é uma expressão das classes sociais no espaço, visto que cada classe terá condições de pagar por residências com características diferentes, implicando na valorização desigual do espaço urbano.

A violência real influência na localização dos residenciais ondem vivem as populações de alto poder aquisitivo. Para Sposito e Goés (2013, p. 166), a violência real são as concretudes de fatos, não subjetivas, que são captadas pelas estatísticas, ainda que precariamente. Explicam ainda que, na dimensão da percepção da violência, que se refere a como o indivíduo percebe a violência, o papel da mídia é fundamental, pois reproduz a violência todos os dias nos meios de comunicação. Pode ocorrer, contudo, que a percepção da violência seja maior do que realmente é na concretude (SPOSITO E GÓES, 2013, p 166).

Em Campos dos Goytacazes, as moradias de alto padrão concentravam-se, predominantemente, no entorno da área central, pois eram e são áreas mais valorizadas historicamente. A população menos abastada ocupava (e ocupa) predominantemente áreas periféricas (FREITAS, 2011, p. 57), sobretudo no subdistrito de Guarus. Esse modelo centro-periferia deu lugar à nova configuração 
do espaço urbano, apresentando-se fragmentado. Os condomínios residenciais fechados vêm atualizando a forma da segregação territorial na cidade nos anos 2000. O subdistrito de Guarus é considerado uma das áreas periféricas mais pobres economicamente e menos servidas pelos equipamentos públicos.

O subdistrito de Guarus (segundo subdistrito) ${ }^{3}$ conta com quarenta bairros, segundo o site do Centro de Informações e Dados de Campos para o Desenvolvimento Amilcar Cabral $\left(\mathrm{Cidac}^{4}\right)$. A população residente no primeiro subdistrito (Centro), de modo geral, enxerga o subdistrito de Guarus como muito violento. O problema em questão é a generalização. Dos quarenta bairros de Guarus, são oito os mais destacados na mídia: Santa Rosa, Parque Guarus, Custodópolis, Jardim Carioca, Parque Aldeia, Cidade Luz, Eldorado e São José. A população trata todo o subdistrito como muito violento. A representação da violência criminosa pela mídia tem papel fundamental na difusão da ideia de que Guarus, enquanto subdistrito, é muito violento. Trata-se da violência da representação.

Dessa forma, investigamos quais as bases reais contidas na representação da violência na cidade e o que corroboraria a segregação residencial de Campos dos Goytacazes, causada pela representação da violência. Há um simbolismo da representação da violência que pode afetar inclusive a escolha dos locais de moradia e o quotidiano da cidade.

Para explicitar a pesquisa realizada, o presente artigo está organizado em três sessões: na primeira, "A segregação residencial em Campos dos Goytacazes: origens da violência urbana", apresentamos o espaço urbano dessa cidade e as origens do processo de segregação residencial; na segunda, "Violência real e representação da violência em Campos dos Goytacazes", trazemos as análises dos dados da violência criminosa e como eles aparecem na mídia. Para finalizar, apresentamos algumas reflexões sobre o processo de urbanização e os problemas urbanos que, como apontamos, não se restringem às metrópoles, mas que têm plena difusão em cidades médias, como Campos dos Goytacazes, ainda que essas portem particularidades.

\section{A SEGREGAÇÃO RESIDENCIAL EM CAMPOS DOS GOYTACAZES: ORIGENS DA VIOLÊNCIA URBANA}

Campos dos Goytacazes, segundo o IBGE (2010), possui uma área de $4.026,370 \mathrm{~km}^{2}$, sendo o maior município em extensão do estado do Rio de Janeiro, com população de 463.731 habitantes. Segundo o CIDAC, a taxa de urbanização em 2010 era de $90,29 \%$, com crescimento de 6,91\% na última década.

No Anuário estatístico de 2015 (CIDAC), o município conta com quatorze distritos: Campos dos Goytacazes (Distrito Sede, subdividido em subdistrito Centro e subdistrito de Guarus), Santo Amaro, São Sebastião, Mussurepe, Travessão, Morangaba, Ibitioca, Dores de Macabu, Morro do Coco, Santo Eduardo, Serrinha, Tocos, Santa Maria, Vila Nova.

\footnotetext{
3 O espaço urbano de Campos dos Goytacazes é organizado em quatorze distritos. O principal distrito é o Sede, que se subdivide em primeiro subdistrito (Centro) e o segundo subdistrito (Guarus). Esse último é fruto da estigmatização.

4 Dados disponíveis no site do Cidac<http:// http://www.cidac.campos.rj.gov.br/dados/PB2014/>Acesso em $27 / 07 / 2015$.
} 
Este artigo tem como recorte espacial o espaço urbano (denominado administrativamente como Distrito Centro) de Campos dos Goytacazes, com cento e três bairros no total. Desses, sessenta e três estão localizados no $1^{\circ}$ Subdistrito Sede e os outros quarenta no $2^{\text {a }}$ Subdistrito Guarus (ambos compõem o distrito Centro da área urbana de Campos dos Goytacazes, conforme Figura 01). A divisão desses dois subdistritos tem como marco o Rio Paraíba do Sul.

Figura 1. Bairros da área urbana de Campos dos Goytacazes (Subdistrito Guarus e Subdistrito Centro do Distrito Sede) - 2017 


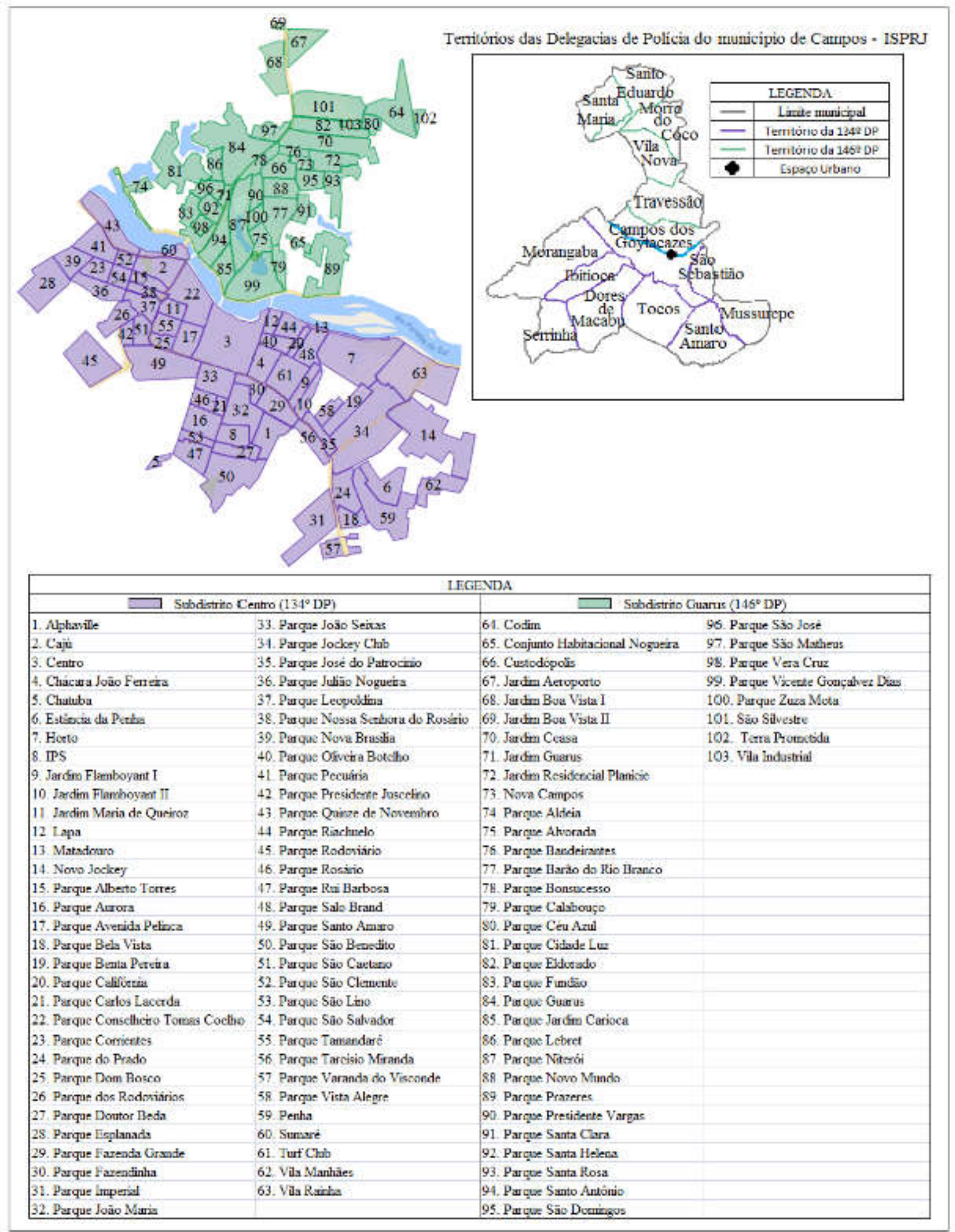

Fonte: Autora, 2017

Por volta de 1675, a área de Guarus era destinada em sesmarias aos índios Guarulhos, para formarem uma aldeia, sob a "proteção" da ordem católica dos padres Beneditinos (VIEIRA; FARIA, 2003, p.12). Por isso, foi dado à área este nome. Em 1677, foi criada a Vila de São Salvador dos Campos dos Goytacazes (atual cidade de Campos dos Goytacazes). Até o fim do século XVIII, enquanto vila, sua economia se baseava na comercialização de mercadorias pelo Rio Paraíba. As 
construções de residências da população pobre eram térreas e de material conhecido como "pau a pique e taipa". As casas das famílias mais abastadas eram imensos sobrados concentrados na área rural, perto dos engenhos (FREITAS, 2011, p. 57).

Campos dos Goytacazes foi um dos primeiros centros urbanos da região Norte Fluminense ${ }^{5}$. Em 1835, passou de vila de São Salvador dos Campos dos Goytacazes à posição de cidade (FARIA, 2005, p.4784). Isso ocorreu por se destacar no cenário nacional na atividade canavieira.

Segundo Faria (2003, p. 13), durante o período colonial, a expansão da área urbana destacou notáveis problemas de insalubridade acometendo o espaço urbano, como terrenos localizados em área pantanosa, péssimas condições dos cortiços e problemas de ordem sanitária (que se agravavam com as inundações).

A partir de então, foram vários os projetos urbanísticos que evidenciavam a diferenciação entre as áreas centrais e periféricas, pois havia a valorização da área central, tendo prioridade nas intervenções públicas, garantindo à burguesia o desenvolvimento e progresso, em detrimento das áreas periféricas, ocupada pelos grupos mais pobres (FARIA, 2005, p.4785).

No final do século XIX, o crescimento do espaço urbano da cidade concentrava-se no entorno da área central, enquanto na área compreendida por Guarus, não se constatava crescimento (FARIA; VIEIRA, 2003, p.13). A concentração dos principais comércios, de solares de senhores de terras, das atividades políticas e sociais na Praça São Salvador tornou-a atrativa, evidenciando sua centralidade (FREITAS, 2011, p. 57).

Em 1880, a cidade se preparava para organizar o espaço urbano por causa das transformações advindas da mecanização dos engenhos. Como indicou o censo de $1920,74 \%$ da população residiam no campo e $26 \%$ na área urbana, evidenciando, portanto, que a maioria da população habitava as áreas rurais.

As transformações ocorridas na área central de Campos foram significativas em razão do auge da produção açucareira. Isso fez com que a população reivindicasse uma comunicação entre o Centro e o Norte da cidade, onde se localizava Guarus. As primeiras construções que concretizaram essa comunicação foram a ponte metálica em 1873 e, mais tarde em 1877, a construção da Estrada de Ferro Campos-Carangola, que atravessava o Centro em direção a Guarus. A partir daí, a população começou a se concentrar próxima à estação, iniciando o crescimento efetivo na área do atual subdistrito Guarus (VIEIRA; FARIA, 2003, p.13).

É perceptível que a dinâmica econômica e as intervenções urbanas tiveram papel importante no crescimento urbano e na configuração urbana atual. Nesse processo, esteve presente a segregação por parte das políticas do Estado, no que diz respeito às intervenções urbanas. Podemos observar que parte das intervenções ocorreu devido à influência das elites. O medo em relação à população pobre, que frequentava e residia nas áreas centrais, pressionou as políticas urbanas. Por meio dos planos urbanísticos, as populações pobres foram retiradas e removidas para a periferia, sobretudo para Guarus. Além disso, a população negra escravizada, após a abolição, teve como local de concentração de suas residências Guarus. Dessa forma, esse subdistrito foi historicamente e territorialmente segregado.

5 A Região Norte Fluminense compreende nove municípios: Campos dos Goytacazes, Carapebus, Cardoso Moreira, Conceição de Macabu, Macaé, Quissamã, São Fidélis, São Francisco de Itabapuana e São João da Barra. Eles exercem atividades de exploração de petróleo, recebendo elevados recursos financeiros advindos do recebimento dos royalties. 
O medo da violência criminosa tornou-se um discurso recorrente nas cidades contemporâneas. Parte desse medo tem como base a realidade, a partir de fatos que ocorrem. Parte da construção do sentimento de insegurança e do medo nas cidades, entretanto, é construída pela mídia, que gera percepções e representações distorcidas sobre o problema. Mesmo quando refletem fatos reais, o foco da mídia sustenta o discurso do medo e não aprofunda a análise da questão. Inclusive propõe soluções que geram mais violência.

$\mathrm{Na}$ atualidade, pode-se observar nas cidades a fragmentação socioespacial e segregação socioespacial, representadas concretamente pelos residenciais fechados. Quanto maior for a violência, seja violência real ou a sensação de violência - essa potencializada pelo discurso midiático -, mais as cidades criam padrões de organização do espaço urbano com base na segregação residencial (CORREA, 2013, p. 43).

\section{A AUTOSSEGREGAÇÃO: A EXPANSÃO DOS CONDOMÍNIOS HORIZONTAIS FECHADOS}

Na década de 1980, houve uma crise quase definitiva para as atividades sucroalcooleiras e, nos anos de 1990, a economia das compensações financeiras (PIQUET, 2007) decorrentes do circuito espacial de produção do petróleo ganha hegemonia política e econômica no Norte Fluminense.

Com o recebimento dos royalties e das participações especiais, Campos dos Goytacazes passa a ter um dos maiores PIBs do Brasil. Esse fato proporcionou investimentos em infraestrutura pública e privada. Aproveitando a economia de petróleo em Campos, os promotores imobiliários investiram em ofertar apartamentos de elevado padrão para uso comercial e empresarial e casas em loteamentos fechados (GOMES, 2015, p. 29).

$\mathrm{Na}$ área urbana de Campos, observa-se que há uma tendência de concentração dos empreendimentos imobiliários no primeiro subdistrito (Centro), mostrando a preferência dos construtores por essa área. Isso acaba por reafirmar sua valorização, tornando-a atrativa para o mercado sob o discurso baseado na qualidade de vida, área verde, lazer, segurança etc. (GOMES, 2015, p. 30).

Em geral, os poucos empreendimentos concentrados na periferia, no subdistrito Guarus, são apartamentos padronizados do Programa Minha Casa Minha Vida ou casas geminadas decorrentes dos projetos habitacionais da Prefeitura, como o Projeto "Morar Feliz". Nessa localidade, podemos encontrar três condomínios para a classe média e somente um de alto padrão.

A concentração de residenciais de alto padrão nas áreas do subdistrito Centro (Figura 02$)^{6}$, bem como a valorização do preço do seu solo, mostra a continuidade de segregação na (re)construção do espaço urbano.

Figura 02: Localização dos condomínios horizontais para as classes média/alta.

\footnotetext{
${ }^{6}$ Os condomínios residenciais Athenas, Damha I, Damha II, Alphaville Campos e Condomínio Royal Boulevard Residence e Resort ocupam o espaço periurbano, configurando a expansão da malha urbana. Os condomínios Granja Corrientes e Hybiscus têm suas entradas de acesso ao condomínio em rua pertencente a bairros vizinhos, porém o condomínio ocupa o espaço dos bairros localizados de acordo com o mapa.
} 


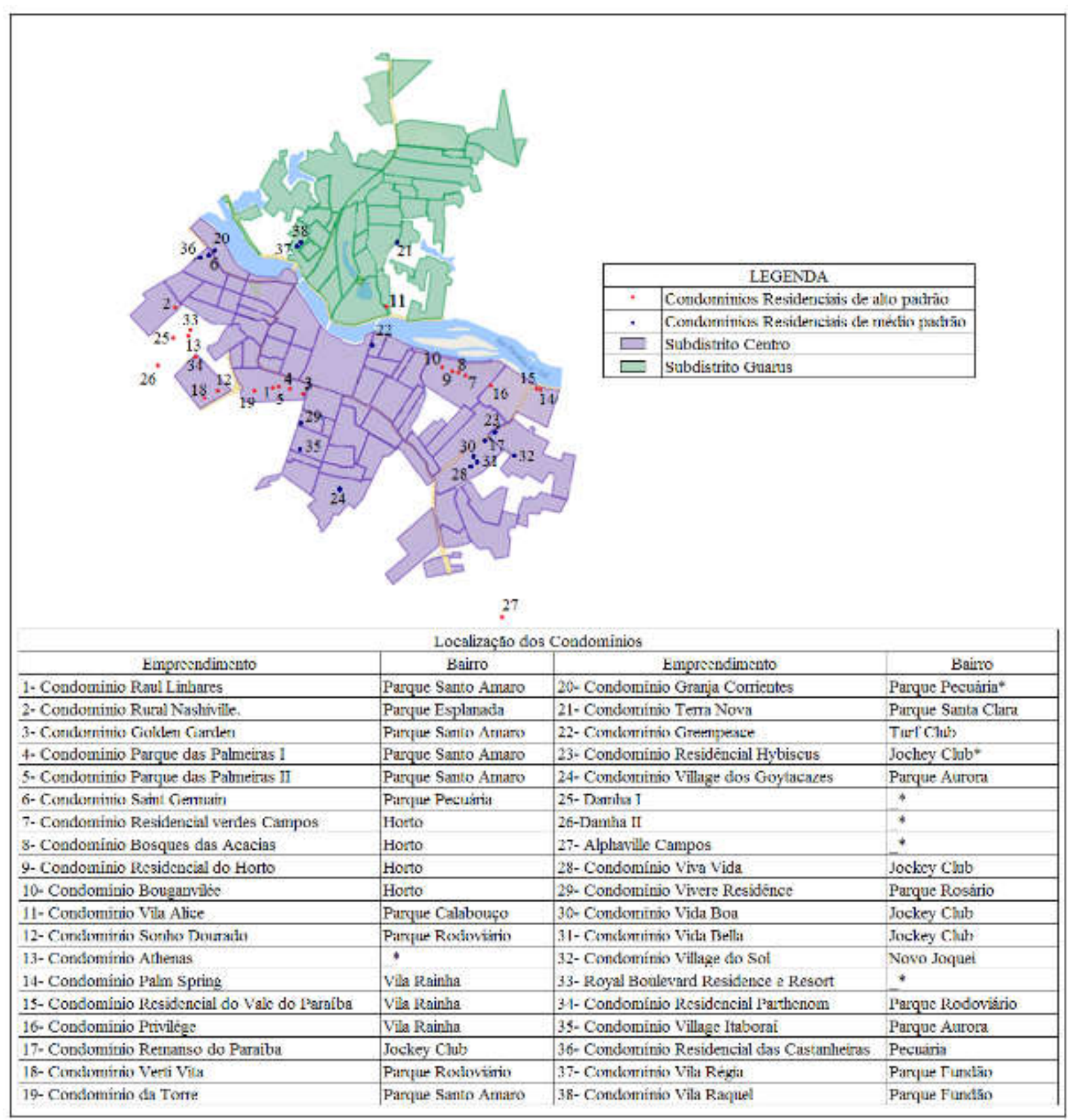

Fonte: Carvalho (2004); Zacchi (2012); Google Maps; Pesquisa direta: Corretores imobiliários; Elaboração da Autora, 2018.

A localização, conforme aponta Villaça (2001, p.72), é um fator primordial na obtenção do lucro da mercadoria moradia. As elites comandam o "caminhamento" da infraestrutura urbana e dominam as áreas melhor equipadas, segundo seus interesses. O signo da segurança tem relevância na escolha da localização, já que a segurança é um signo comprado, cujo valor está agregado ao da moradia a ser adquirida (FREITAS, 2011, p. 69).

Podemos observar que, no subdistrito Centro, os residenciais horizontais se concentram na área periférica do espaço urbano do centro ${ }^{7}$. Os localizados no subdistrito de Guarus ficam próximos a pontos de acesso ao Centro, já que a

\footnotetext{
${ }^{7}$ Ressaltamos que em uma cidade média como Campos dos Goytacazes, a área periférica, onde se localizam os condomínios residenciais fechados, é muito próxima ao centro (raramente ultrapassando 20 minutos de carro para acesso ao Centro).
} 
proximidade com a área central é um dos pontos favoráveis para a valorização e o marketing desses imóveis.

O preço final da moradia está determinado pela construção, localização e símbolos nele embutidos. Guarus, no processo histórico, foi e é negligenciado pelas intervenções urbanas. Quando recebe investimentos no setor imobiliário, são de estruturas de qualidade inferiores. Além desses fatores, pode-se incluir a imagem negativa do local, que é considerado muito violento, no caso da violência criminosa. A população que deseja adquirir uma moradia não deseja residir em uma área considerada violenta.

A insegurança e a violência têm sido fatores importantes na produção e valorização desigual do espaço urbano. É a partir delas que os promotores imobiliários descartam espaços considerados violentos, mantendo o discurso de segurança embutido na estratégia de marketing. Isso traz uma valorização simbólica dos espaços, reafirmando a desvalorização de uma área com alto índice de violência criminosa.

O medo da violência criminosa tornou-se um discurso recorrente nas cidades contemporâneas. Parte desse medo tem como base a realidade, a partir de fatos que ocorrem, entretanto parte da construção do sentimento de insegurança e do medo nas cidades é construída pela mídia, que gera percepções e representações distorcidas sobre o problema. Mesmo quando refletem fatos reais, o foco da mídia sustenta o discurso do medo, não aprofunda a análise da questão e inclusive propõe soluções que geram mais violência.

$\mathrm{Na}$ atualidade, pode-se observar nas cidades a fragmentação socioespacial e segregação socioespacial, representadas concretamente pelos residenciais fechados. Quanto maior for a violência, seja violência real ou a sensação de violência - essa é potencializada pelo discurso midiático -, mais as cidades criam padrões de organização do espaço urbano com base na segregação residencial (CORRÊA, 2013, p. 43), potencializados pelos promotores imobiliários.

Para Zacchi (2012, p. 148), a sensação de insegurança tem servido de estímulo para a autossegregação e isolamento das camadas de alto poder aquisitivo (Gráfico 1). Essa sensação é baseada no aumento da violência e criminalidade urbana, que tem uma forte contribuição das notícias difundidas pela mídia.

No espaço urbano em Campos dos Goytacazes, é incontestável que houve grande surgimento de condomínios residenciais fechados nas áreas periurbanas no primeiro subdistrito (Centro), firmando a falta de interesse, por parte dos grupos sociais de alto status, em ter a periferia em Guarus como localização de suas residências.

É importante analisar a causa desse desinteresse pela área periférica localizada ao Norte do espaço urbano do município, já que a periferia do subdistrito Centro apresenta intensos investimentos imobiliários de habitações destinadas às classes mais abastadas, conformando uma nova área periférica.

Gráfico 1: Principais razões que levaram os cidadãos a residir em condomínios. 


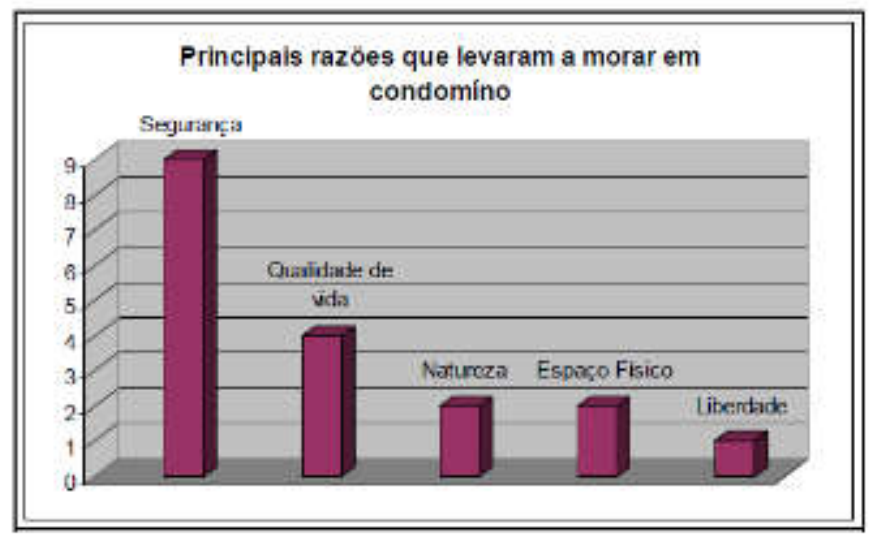

Fonte: Zacchi (2012, p. 148)

É perceptível que a proximidade dos menos abastados não é um empecilho para se habitar a periferia, já que haverá uma separação por estrutura física, o muro, ou outras materialidades que simbolizam a separação física. Um fator, contudo, que se torna um obstáculo para o interesse dessas camadas sociais, bem como para o investimento dos produtores imobiliários, é o alto índice de violência em Guarus, pois seria contraditório vender segurança, e ter como localização das habitações um local violento. Assim, o espaço urbano de Campos tem se configurado em uma nova estrutura periférica na área referente ao primeiro subdistrito, adquirindo novas formas de uso, sendo fragmentada e diversificando a ocupação do seu solo. Enquanto na outra parcela do espaço urbano localizado em Guarus, são escassos os residenciais fechados de alto padrão.

\section{VIOLÊNCIA REAL E REPRESENTAÇÃO DA VIOLÊNCIA EM CAMPOS DOS GOYTACAZES}

A violência urbana vem crescendo, assumindo novos aspectos e formas, daí surge a importância da discussão sobre a violência. $O$ discurso do medo tem aumentado não somente contra determinados grupos sociais, mas também contra determinados espaços, que são estigmatizados como violentos a priori, tornando-se objetos de preconceitos e de aprofundamento da segregação socioespacial.

A violência criminosa, no senso comum das classes sociais de renda elevada e das classes médias, geralmente está associada à presença de grupos sociais de menor poder aquisitivo. Com isso, há o desejo de que tais grupos sociais se localizem o mais distante possível, aumentando o processo de segregação socioespacial. $\mathrm{Na}$ atualidade, pode-se observar nas cidades a fragmentação socioespacial representada concretamente pelos residenciais fechados. Quanto maior for a violência, seja ela real ou apenas a sensação de violência (potencializada pela mídia), mais as cidades criam padrões de organização do espaço urbano com base na segregação residencial. Conforme apontamos anteriormente, esse é um processo presente em Campos dos Goytacazes.

A população residente no subdistrito Centro concebe o subdistrito Guarus como muito violento. Entretanto essa insegurança em relação a Guarus e seus moradores, em grande medida, está baseada em noticiários que expandem fatos ocorridos em determinados bairros e noticiam destacando o segundo subdistrito, chamando atenção para a palavra "Guarus". Como vimos, porém, o subdistrito conta 
com quarenta bairros, e a violência não se apresenta homogênea no subdistrito. Além disso, esse espaço tem sido construído por condicionantes históricos e espaciais de segregação de grupos sociais mais pobres, desconsiderando que essa população é a mais sujeita à violência, inclusive à violência policial. Ignora-se também que ela é submetida ao descaso em relação à segurança e às políticas públicas em geral, como saúde, educação, saneamento, lazer, etc.

Com base em Sposito e Góes (2013, p. 166), podemos identificar três dimensões da violência. A primeira refere-se a como o indivíduo percebe a violência. A mídia tem papel fundamental, pois reproduz a violência todos os dias nos meios de comunicação. O problema é que a percepção da violência pode ser maior do que realmente é na realidade (SPOSITO E GÓES, 2013, p 166). Isso gera uma complicação ainda maior, visto que se a população tem a sensação de insegurança exagerada pelo fato da sua percepção sobre a violência ser exacerbada, pode-se então haver segregações geradas por violências representadas, que na verdade não ocorrem de fato. Em outras palavras, acabam ocorrendo segregações, baseadas somente na percepção. A segunda diz respeito a fatos de violência concretos, observados por meio dos dados, que seriam inegáveis, pois apresentam provas materiais. Por último, as explicações, que são resultado dos acontecimentos traumáticos das pessoas, denominadas como a fala do crime por Caldeira (2011, p. 27).

Nesta pesquisa, a violência foi analisada, na perspectiva de Sposito e Góes $(2013 \text {, p. 167 })^{8}$, como uma instituição social que agride o corpo, a psique e a consciência de pessoas, bem como comunidades, classes sociais e etnias. Embasadas nessas mesmas autoras, compreenderemos a violência real como fato concreto da violência criminosa, algo que é captado pelas estatísticas, ainda que essas sejam precárias e muitas vezes não acessíveis. Já a representação da violência se refere à influência cotidiana da mídia na disseminação da sensação de violência. $O$ caráter difuso da violência ocorre graças à presença repetida e sensacionalista que os meios de comunicação garantem todos os dias, fazendo com que, muitas vezes, o particular assuma o papel de regra. Então, a mídia apresenta caráter manipulador, visto que ela introduz certa ordem indicando o que se deve fazer e evitar para não ser vítima de uma violência exagerada que ela mesma criou. Sendo assim, ocorre a violência da representação. Ao mesmo tempo em que a mídia representa, ela é uma nova forma de violência (SPOSITO E GOÉS, 2013, p. 173).

Para entender o papel da mídia impressa nas representações sobre a violência urbana e suas influencias nas representações da população, fez-se necessário analisar como a violência é abordada na mídia local. Para isso, analisamos os jornais O Diário e Folha da Manhã, no período de 2003 a 2015. Ao analisar os jornais, constatamos que os principais delitos representados são: homicídio, estupro, roubo a estabelecimento comercial, roubo a transeunte, roubo a residência e roubo a instituição financeira.

A representação da violência criminosa na mídia pode ser explicada por meio de duas estratégias: o efeito miopia e o efeito zoom, conforme explicam Sposito e Goés (2013, p. 173). O primeiro ocorre quando o foco é direcionado exclusivamente a uma situação atual, perdendo-se de vista acontecimentos anteriores, ou seja, a mídia tem o poder de selecionar quais matérias vão ser propagadas e em quais irão focar. O efeito zoom ocorre quando a mídia ignora a contextualização dos fatos e seleciona casos geralmente chocantes para abordar, o que prende a atenção do

\footnotetext{
${ }^{8}$ Sposito e Góes (2013) fundamentam-se em Moarais (1985) e Taille (2000) quanto à concepção de violência.
} 
espectador. Confirma-se, a partir disso, o caráter gerador de insegurança na população propagado pela mídia, seja ela concreta ou não.

Essas representações midiáticas também influenciam as representações da população denominada por Caldeira (2011, p. 29) como a fala do crime. As conversas do dia-a-dia também têm papel fundamental na construção do medo. Em Campos dos Goytacazes, essas representações populares chegam a acontecer no mundo virtual, sobretudo gerando falas contra o subdistrito de Guarus. Podemos nos deparar com imagens que representam Guarus como um local muito violento, como uma área onde só se encontram pobres e criminosos, imagens que representam uma segregação socioespacial simbólica que agride a psique dos moradores dessa parte da cidade.

Caldeira (2011, p 57) apontou que as experiências de violências tendem a ser específicas de cada classe. Pessoas de diferentes camadas sociais são vítimas de diferentes tipos de delitos, sendo a classe trabalhadora mais afetada pelos crimes mais violentos ${ }^{9}$. Dessa forma, o medo da violência criminosa influencia o direcionamento dos condomínios residenciais.

Analisamos a violência criminosa real a partir de dados do Instituto de Segurança Pública do Rio de Janeiro (ISPRJ), fazendo comparações entre os dados dos delitos ocorridos no território da $136^{\circ} \mathrm{DP}$ (Delegacia localizada no subdistrito Centro) e no território da $146^{\circ}$ DP (Localizada no Subdistrito Guarus) ${ }^{10}$ para conferir se há realmente uma concentração dos crimes em Guarus. Em seguida, abordamos o tratamento da mídia nos jornais no período de 2003 a $2015^{11}$.

\section{A VIOLÊNCIA CRIMINOSA, A REPRESENTAÇÃO DA VIOLÊNCIA E A VIOLÊNCIA DA REPRESENTAÇÃO EM CAMPOS DOS GOYTACAZES}

Para a análise da violência criminosa em Campos dos Goytacazes, foi feito o levantamento de dados no período de 2003 a 2015 das ocorrências de crimes no município segundo as unidades territoriais das duas delegacias de polícia presentes no município, a $146^{\circ} \mathrm{DP}$, localizada no subdistrito de Guarus, e a $134^{\circ} \mathrm{DP}$, situada no subdistrito Centro. Destacamos quatro crimes que consideramos como aqueles que mais chocam e agridem a população e também são bastante recorrentes: o estupro, o homicídio, o roubo a transeunte e o roubo a residência.

O estupro é um crime com registros considerados geralmente subestimados como decorrência de fatores que inibem as (os) agredidas (dos) a registrarem a ocorrência. Sabemos que os dados oficiais são precários, mas os tomamos como ponto de referência. No período analisado, os números foram crescentes. Esse fato ou pode representar realmente o crescimento no número de casos, ou pode ser que as vítimas tomaram, nesses últimos anos, mais coragem para denunciar. $O$ homicídio, dentre os delitos analisados, é o que menos apresenta distorções nos dados, porém Caldeira (2011, p. 104) já aponta a problemática nas classificações de crimes organizadas pelas instituições públicas. Os roubos de maneira geral são mais

\footnotetext{
9 Ressaltamos também que a violência acomete de forma diferente os grupos sociais, tendo influência a situação de gênero, a etnia e até mesmo a idade, sendo o espaço também condicionante a maior ou menor sujeição à violência.

10 Apesar de todos os esforços, não tivemos acesso aos dados das ocorrências por bairros em Campos dos Goytacazes.

${ }^{11}$ Os registros e divulgação da série histórica dos dados estatísticos no ISPRJ tiveram início em 2003, por isso o recorte desse período para a avaliação.
} 
recorrentes no subdistrito Centro. Nesse sentido, destacamos para análise o roubo a transeunte, por ser o tipo de delito que é mais recorrente entre os demais roubos. $O$ roubo a residência, embora tenha números poucos expressivos se comparado aos demais escolhidos, é de relevância para tentar entender como a população de médio/alto poder aquisitivo se sente insegura dentro de sua própria casa. Preferem ficar reclusos em condomínios residenciais fechados com todo o tipo de estratégias de proteção, tais como câmeras, guardas, muros e cercas elétricas.

No Gráfico 2, podemos verificar a comparação das ocorrências de Homicídio doloso entre a unidade territorial referente a $146^{\circ}$ DP (Guarus) e a $134^{a}$ DP (Centro) no período de análise da pesquisa. A área Norte do município representada pela $146^{a}$ DP apresenta índice superior à área Sul. Durante os sete primeiros anos, as oscilações nas ocorrências de ambas as unidades parecem coincidirem.

Gráfico 2. Comparação das ocorrências de Homicídios Doloso entre as unidades territoriais da $134^{a}$ DP (Centro) e 146 ${ }^{a}$ DP (Guarus) por 50.000 hab (2003 a 2015).

Fonte: Autora

$\begin{array}{lr}\text { De forma } \\ \text { mídia } & \text { costuma } \\ \text { crimes } & \text { mais } \\ \text { e o homicídio é } \\ \text { em r constante } \\ \text { Como os dados } \\ \text { na área coberta } \\ \text { crime r é }\end{array}$

como

quência, essas

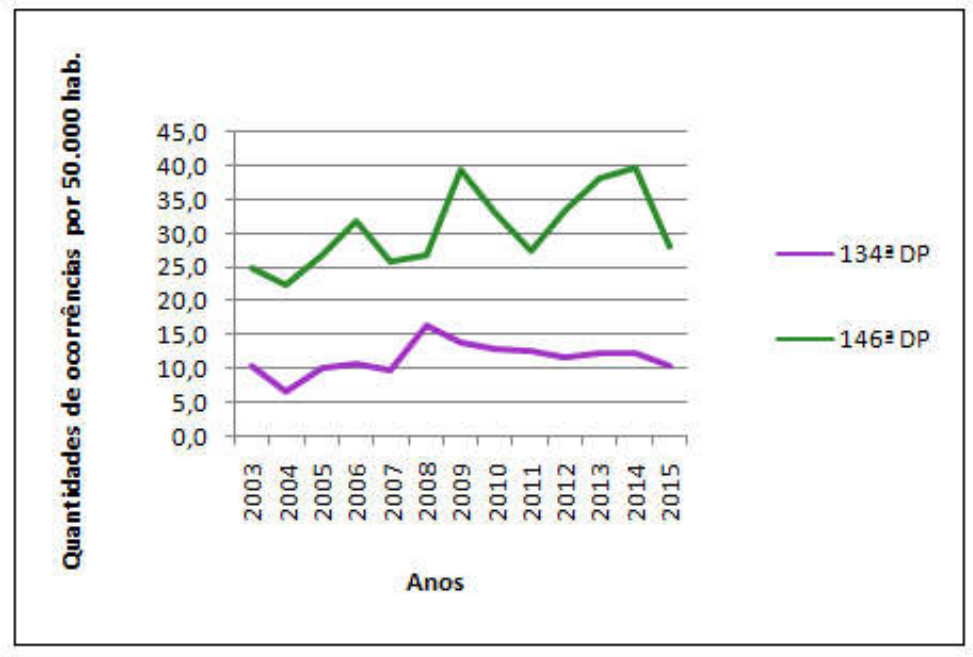

(2017)

geral, a mostrar os chocantes, o que está evidência. mostram, pela $146^{\mathrm{a}} \mathrm{o}$ frequente; conseáreas

serão mais exploradas pela mídia. Isso pode causar na população grande sentimento de insegurança e medo em relação a essa região da cidade. Isso combinado com os preconceitos concebidos historicamente em Campos dos Goytacazes em relação a todo esse território.

A explicação para os elevados números de homicídios relaciona-se com as disputas por territórios entre duas facções do tráfico de trocas, a A.D.A. (Amigos dos Amigos) e T.C.P. (Terceiro Comando Puro). Segundo o chefe de serviço da comissão de polícia da $146^{\mathrm{a}} \mathrm{DP}^{12}$, que já exerce a profissão há 30 anos, o grande número de homicídios na cidade deve-se em grande parte a essa disputa. De fato, os dados mostram que em Guarus eles são maiores que no subdistrito Centro.

No subdistrito Guarus, segundo informações da polícia, o número de homicídios aumentou depois que houve a "mistura" de facções com o programa habitacional Minha Casa Minha Vida e com o programa municipal "Morar Feliz". Dentre os bairros com alto índice de homicídio estão Eldorado, São Silvestre, Santa Helena, Santa Rosa, Cidade Luz, Fundão e Jardim Carioca.

Observando a Figura 3, podemos perceber que os bairros de Guarus são os mais noticiados, com destaque para os bairros Custodópolis, Jardim Carioca e Santa Rosa. Já no subdistrito Centro, o bairro Parque Aurora foi o mais noticiado, porém

\footnotetext{
${ }^{12}$ Entrevista realizada em 08/04/2017.
} 
não chegando a ter, em números absolutos, maior destaque que o bairro mais noticiado em Guarus.

Em 2006, o número de notícias de homicídios é maior que em 2003. Podemos observar que no subdistrito Centro alguns bairros são mais noticiados três anos depois, em 2006, porém as repetições dos bairros são menores. Já no subdistrito Guarus, alguns bairros são mais noticiados, ou seja, alguns bairros ficam em mais evidência na mídia. Como acontece com os bairros Santa Rosa - que já apresentava essa exploração pelo jornal desde 2003 —, o Parque Aldeia, Parque Guarus, Parque São José e Jardim Carioca.

Figura 3. Bairros mais noticiados em relação ao crime de homicídio nos anos de 2003 e 2006 - Campos dos Goytacazes.

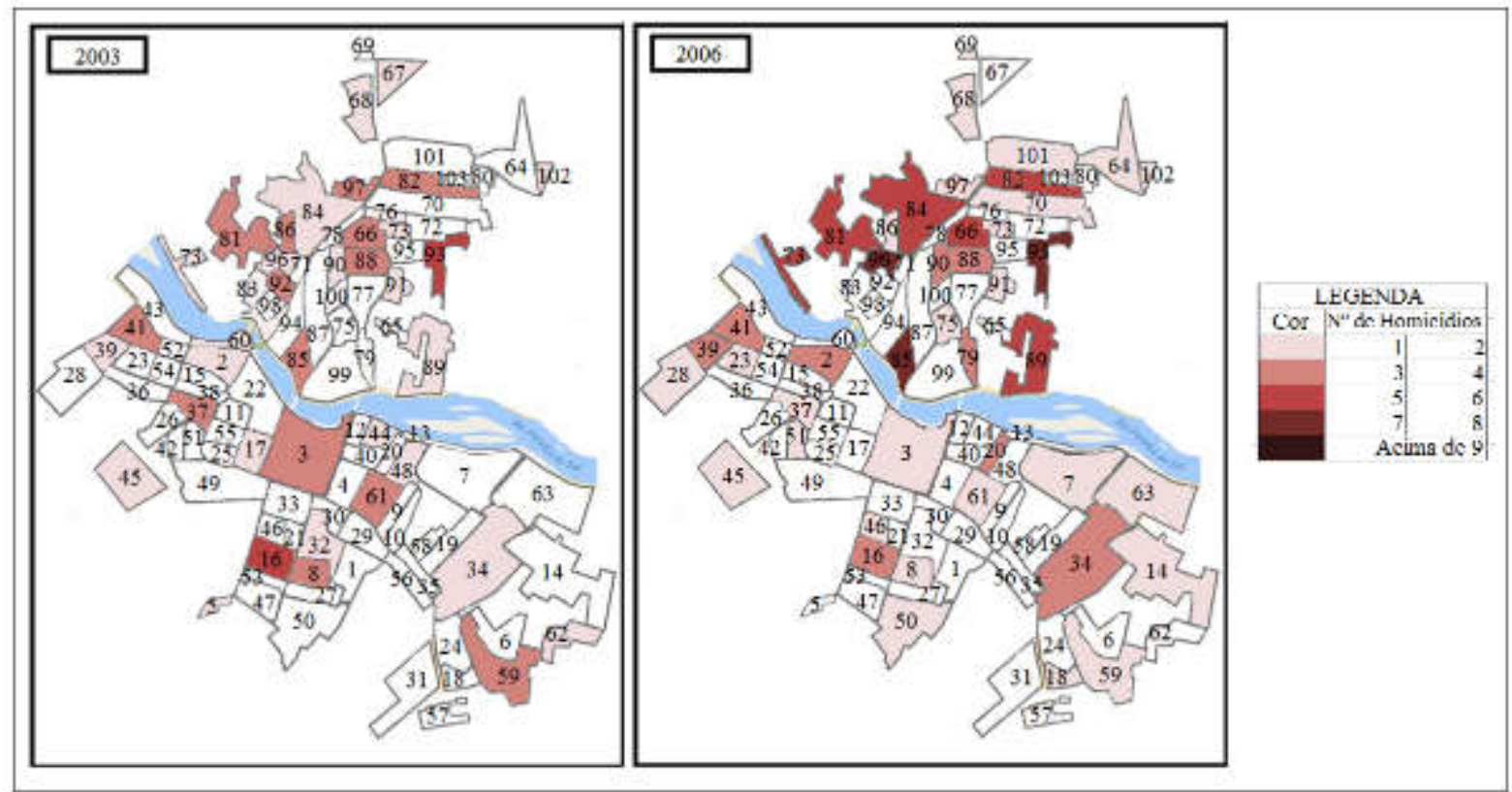

Fonte: Jornal O diário; Autora (2017)

Observamos que os crimes que ocorriam nos bairros em Guarus ganhavam mais capas, sobretudo destacando "Guarus". Mesmo com a quantidade inferior, entretanto, as capas do subdistrito Centro eram reservadas aos fatos que ocorriam com pessoas de alto poder aquisitivo.

Podemos constatar que os jornais O Diário e Folha da Manhã exploram muito as matérias sobre a violência. O jornal Folha da Manhã várias vezes usou expressões como "extermínio de gente" ou "escalada da violência" para dar impacto e chamar a atenção para a matéria, fato que alimenta o sentimento de insegurança. Ainda, o jornal Folha da Manhã, nos últimos anos, fazia contagem de homicídios em suas capas.

No ano de 2009 (Figura 4), os bairros Centro e Penha aparecem com mais frequência, assim como o Novo Jockey, Matadouro e Parque Califórnia. No subdistrito Guarus, os bairros Santa Rosa, Jardim Carioca e Custodópolis são mais noticiados.

$\mathrm{Na}$ maioria das notícias do jornal Folha na Manhã sobre delitos no bairro Custodópolis, onde se localiza a $146^{a} \mathrm{DP}$, havia a informação que crime noticiado aconteceu próximo a essa delegacia de polícia. Esse fato traz a percepção de uma polícia despreparada, que não consegue conter a criminalidade. Isso somado às 
intensas abordagens de crimes nos bairros do subdistrito traz a sensação de violência sem controle.

Em 2013, os homicídios ocorridos nos bairros do subdistrito Centro são menos noticiados, tendo concentração nos bairros Centro e Novo Jockey. No subdistrito Guarus, nesse ano, são mais noticiados os homicídios ocorridos no bairro Cidade Luz e São José.

Figura 4. Bairros mais noticiados com relação ao crime de homicídio nos anos de 2009 e 2013 - Campos dos Goytacazes.
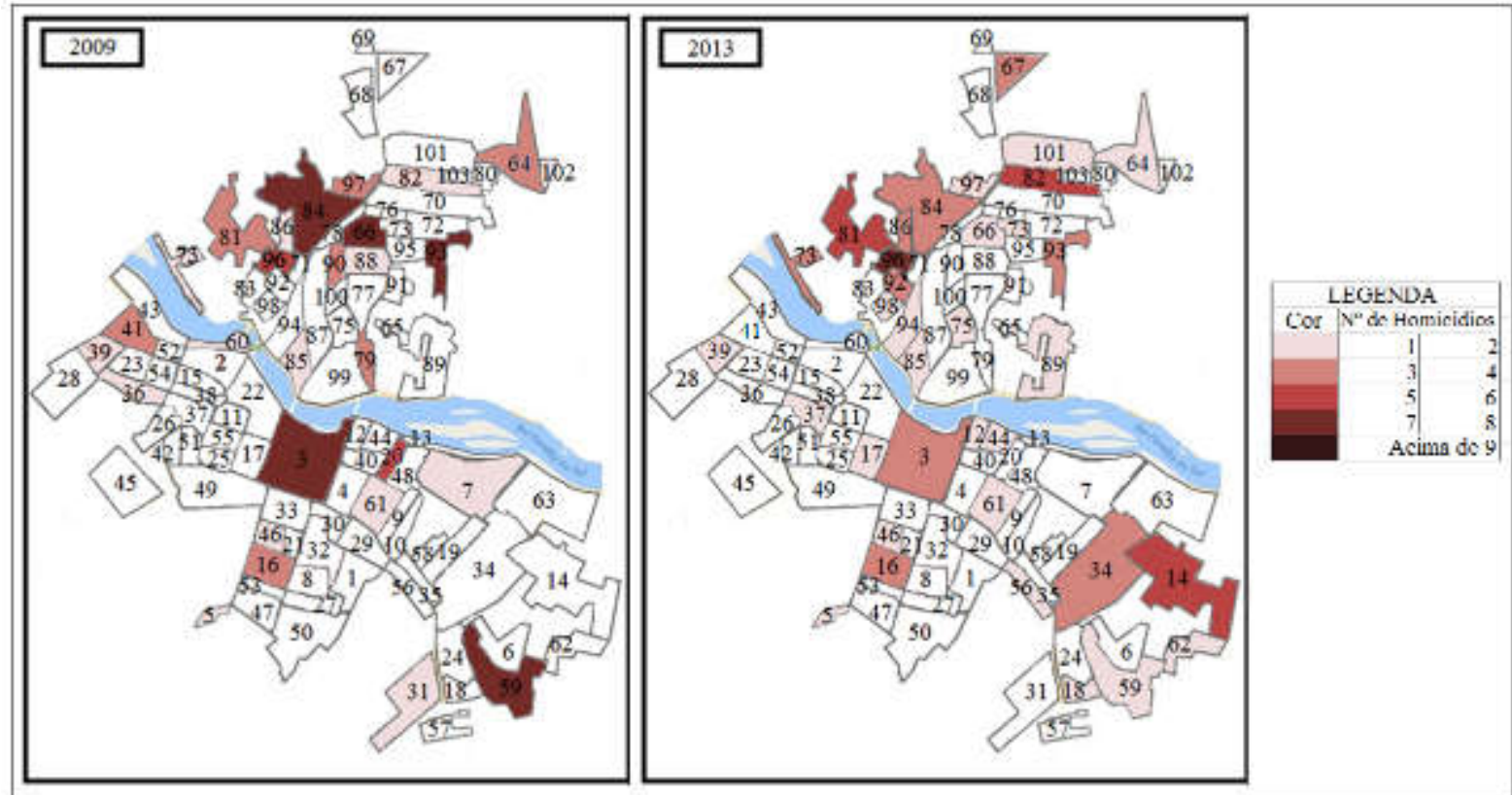

Fonte: Jornal O diário; Autora (2017)

Em 2015 (Figura 5), os homicídios ocorridos no primeiro subdistrito (Centro) quase não são noticiados. Os bairros Parque Aurora e Turf Club estão em sutil destaque, pois apresentam frequência bem inferior nas mídias em relação aos bairros do subdistrito Guarus.

Analisando esses dados, podemos constatar que os bairros do subdistrito Centro mais evidentes na mídia são: Parque Aurora, Centro, Novo Jockey e Penha. Evidencia-se que esses bairros não são os que têm recebido os residenciais fechados. No segundo subdistrito, podemos destacar Santa Rosa, Parque Guarus, Custodópolis, Jardim Carioca, Parque Aldeia, Cidade Luz, Eldorado e São José.

Figura 5. Bairros mais noticiados em relação ao crime de homicídio no ano de 2015 - Campos dos Goytacazes 


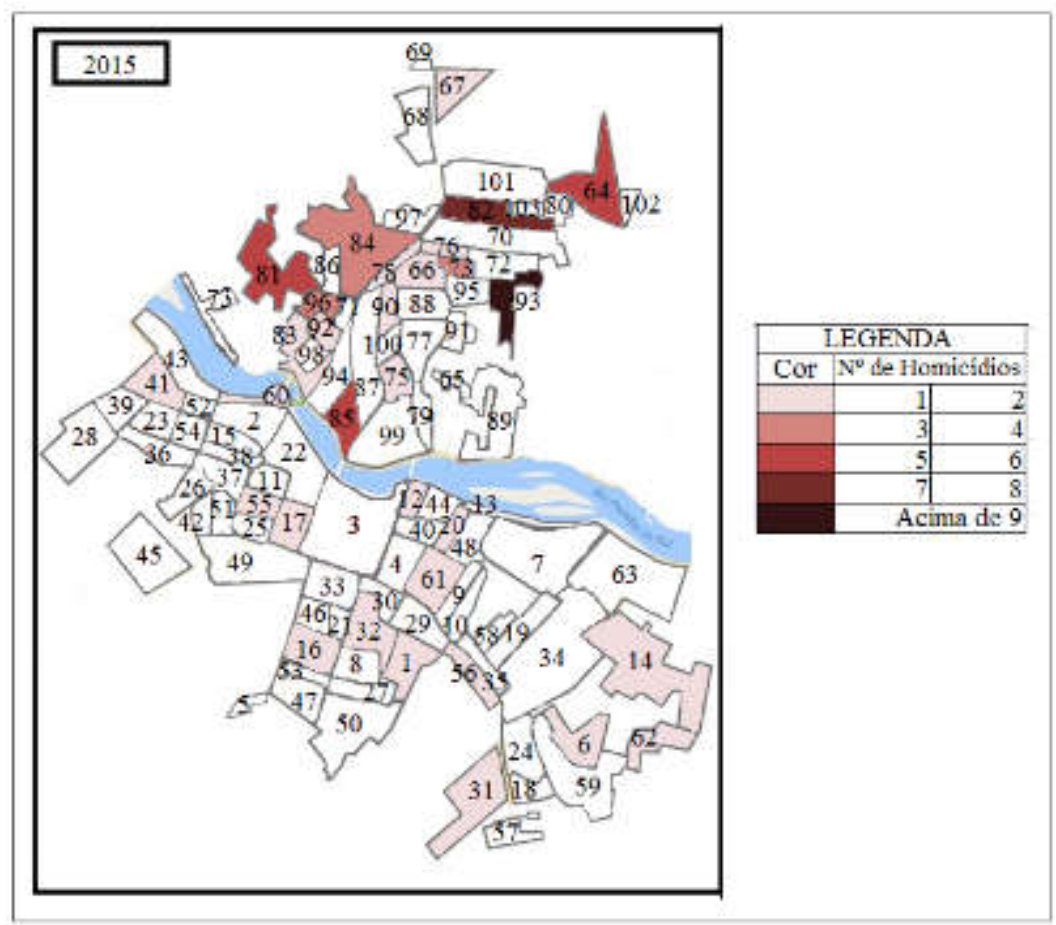

Fonte: Fonte: Jornal O diário; Autora (2017)

No que diz respeito ao roubo a transeunte, o Gráfico 3 evidencia maior incidência no território da $134^{\mathrm{a}}$ DP (Centro). Nos anos iniciais, constata-se maior disparidade entre as áreas analisadas. Nos últimos cinco anos, essa discrepância diminui e no ano de 2014 ocorre à inversão, com a 146 $\mathrm{aP}$ (Guarus) tendo maiores ocorrências. No último ano, ocorre significativa queda nas ocorrências de roubo a transeunte na área da $146^{a} \mathrm{DP}$, voltando a $134^{\mathrm{a}} \mathrm{DP}$ a ter mais ocorrências. Os roubos de forma geral não são evidenciados pela mídia, exceto casos específicos como o latrocínio, que costumam trazer grande impacto ao público, notadamente se ocorrerem com pessoas pertencentes às classes média ou alta.

Gráfico 3. Comparação das ocorrências de Roubo a Transeunte entre as unidades territoriais da $134^{\mathrm{a}}$ DP e $146^{\mathrm{a}}$ DP por 50.000 hab. (2003 a 2015).

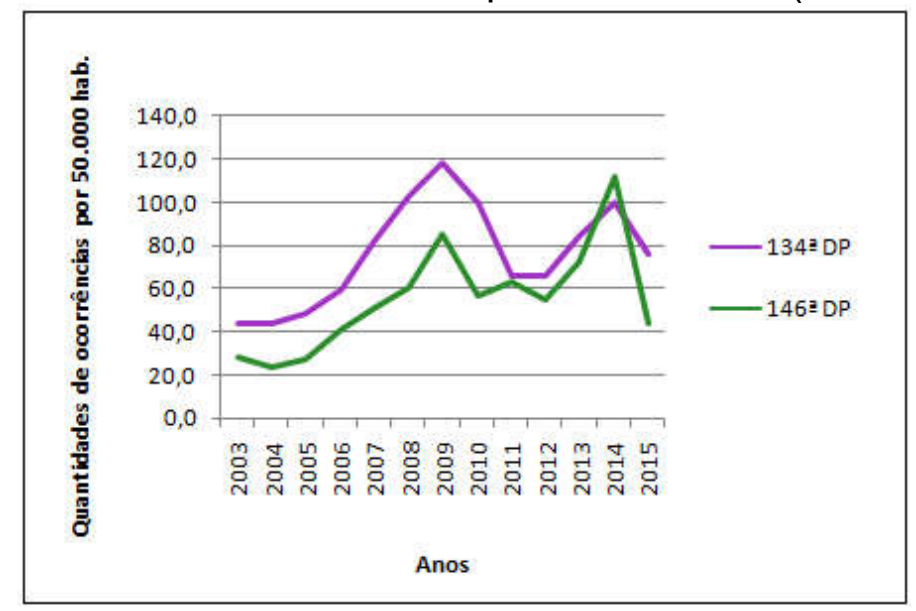

Fonte: Instituto de Segurança Pública; Autora (2017). 
Nos anos iniciais do período de análise, o roubo a transeunte, embora pouco noticiado, foi o mais contabilizado, sobretudo no bairro Centro. Na Figura 6, em 2003, podemos ver que os bairros que aparecem são Centro, Parque Tamandaré, Dom Bosco, João e Maria, IPS, Turf Club, ou seja, bairros próximos a áreas centrais, sobretudo, bairros onde reside a classe média/alta. Isso evidencia que esse tipo de delito ocorre mais nas áreas dos bairros com maiores rendas, causando sentimento de insegurança nessa população.

Figura 6. Bairros mais noticiados em relação ao crime de roubo a transeunte nos anos de 2003 e 2006 - Campos dos Goytacazes.

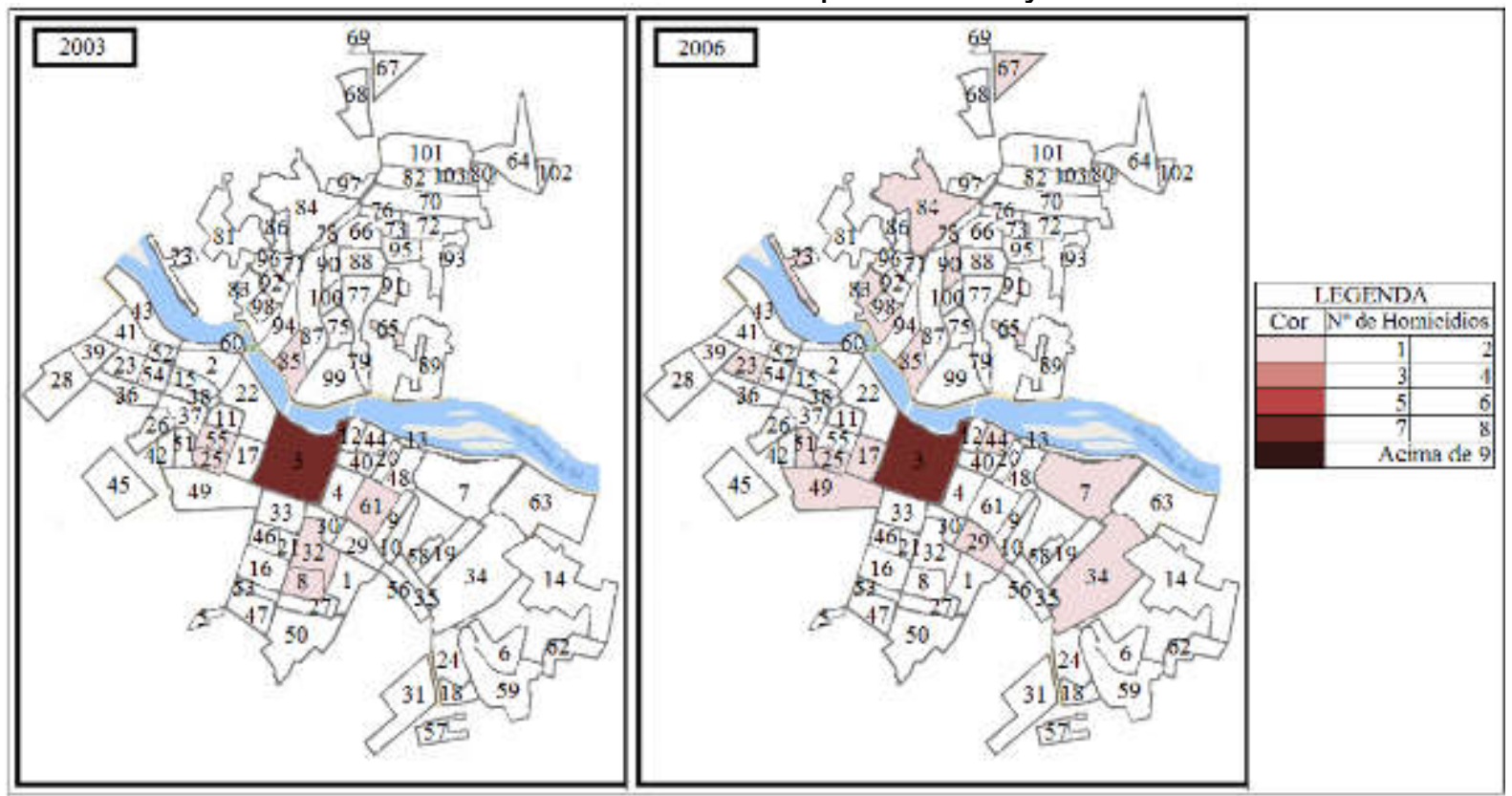

Fonte: Jornal O diário; Autora (2017)

Em 2006, o destaque continua sendo o bairro Centro, local de intenso fluxo de pessoas, pois aí se localiza o centro comercial mais frequentado pela classe de menor poder aquisitivo. O bairro Pelinca, onde surgiu uma nova centralidade centro expandido -, com lojas voltadas para a população de médio e alto poder aquisitivo, não aparece com frequência, surgindo notícias somente no ano de 2006. Esse fato mostra que, embora os crimes de roubo ocorram nas áreas nobres, não é interessante que eles apareçam como muito violentos. Já em Guarus, alguns bairros que aparecem com bastante repetição no crime homicídio também ganham o mesmo destaque na mídia no roubo a transeunte, igualando-se com os bairros do Centro. Isso gera a sensação de que esse tipo de delito ocorre com as mesmas proporções em ambos os distritos.

Em 2009 e 2013, ocorreu a redução nos totais de notícias desse delito. Em 2009, somente dois bairros aparecem na mídia: o Parque Rodoviário, localizado no subdistrito Centro, e o bairro Jardim Carioca. Os roubos que aconteceram nesse último, porém, foram bem mais noticiados, ou seja, há a sensação de que ocorreram roubos em maior proporção no subdistrito Guarus. Em 2013, embora pouco representado, esse delito se apresenta de igual proporção entre os dois subdistritos.

Em 2015, houve redução significativa das notícias desse delito, somente dois bairros do subdistrito Centro estão nas representações. No período entre 2003 a 2015, as notícias desse crime apresentam diminuição, fato que entra em contradição com os dados reais (Estatísticas do ISPRJ), que apresentam aumento nesse mesmo 
período. Outro fator a destacar é que as notícias de homicídios desse mesmo período nos jornais apresentam aumento, sobretudo sobre o subdistrito Guarus. Podemos observar a super evidência do bairro Eldorado nesse tipo de violência, que em 2015, foi representada vinte e uma vezes.

Sendo assim, a mídia não evidencia o aumento de roubo a transeunte nos bairros em que esse crime acontece com mais frequência - nas regiões mais nobres - ao passo que o homicídio, que afeta mais intensamente a população pobre, tem muita representação. Isso demonstra que a mídia não representa negativamente as áreas mais nobres da cidade.

$O$ roubo a transeunte, dentre os delitos analisados, foi o segundo maior em notícias. Nos últimos anos, o número de notícias desse delito diminuiu consideravelmente em ambos os jornais. Fato esse que é bem discrepante se compararmos com os dados reais (das estatísticas do ISPRJ), que estão entre as maiores ocorrências. Esse delito não prende a atenção dos leitores, não é um crime que choca. Houve também a diminuição nos números de capas. Quase não podemos observar destaque a esse tipo de delito em capas. De 2003 a 2008, tivemos as maiores quantidades de notícias divulgadas sobre os bairros localizados no subdistrito Centro.

Na Figura 7 e na Figura 8, podemos observar que de 2009 a 2015, com números bem inferiores, apresentou-se pouca diferença entre as localidades. De maneira geral, as notícias de roubo a transeunte apresentavam três tipos: a pedestres e a taxistas no bairro do Centro, a ônibus e a caminhões de carga no subdistrito de Guarus e a transportadores em bairros e distritos que são cortados pela BR 101.

Figura 7. Bairros mais noticiados em relação ao crime de roubo a transeunte nos anos de 2009 e 2013 - Campos dos Goytacazes.

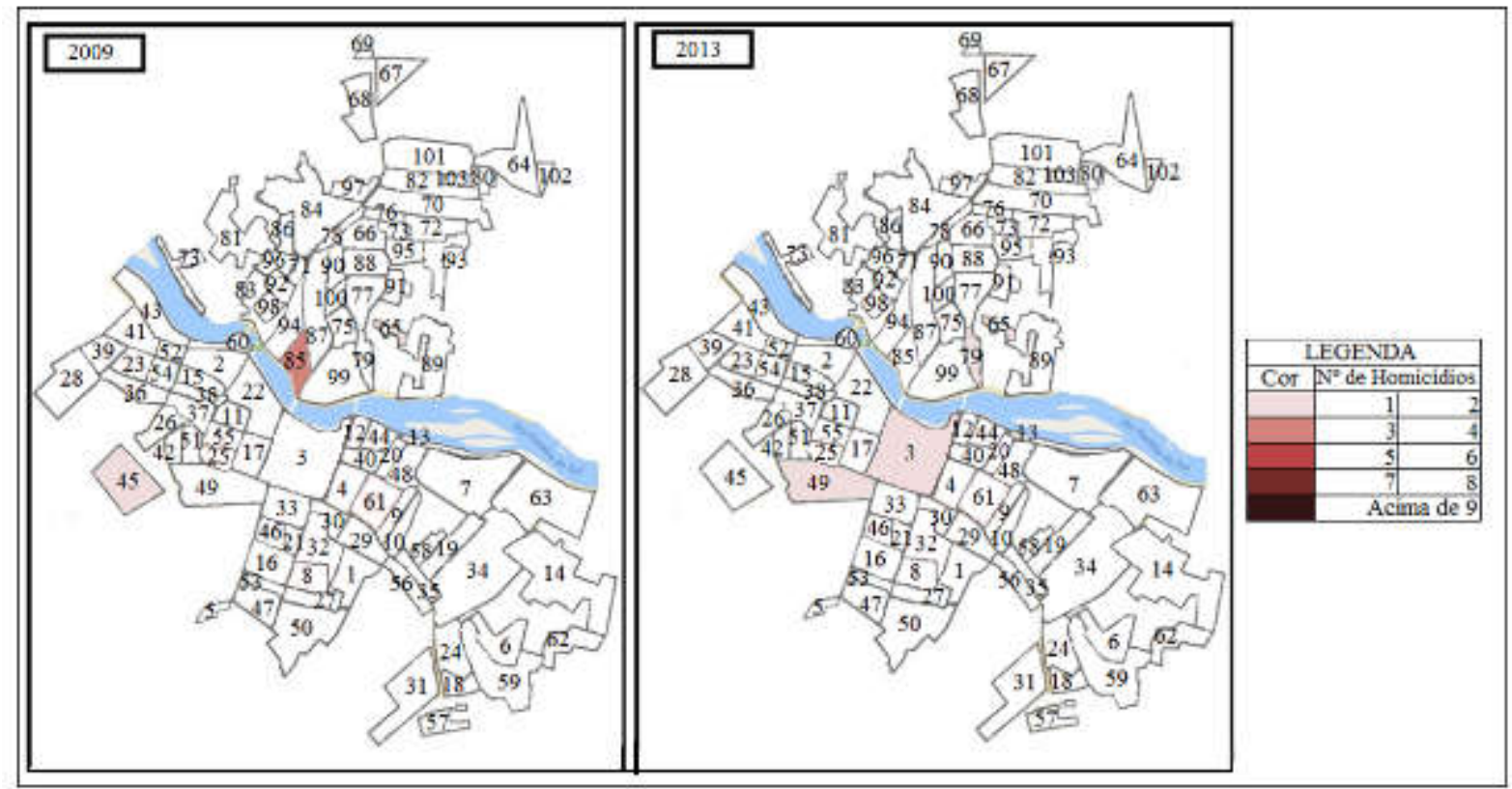

Fonte: Jornal O diário; Autora (2017) 
Figura 8. Bairros mais noticiados em relação ao crime de roubo a transeunte nos anos de 2015 - Campos dos Goytacazes.

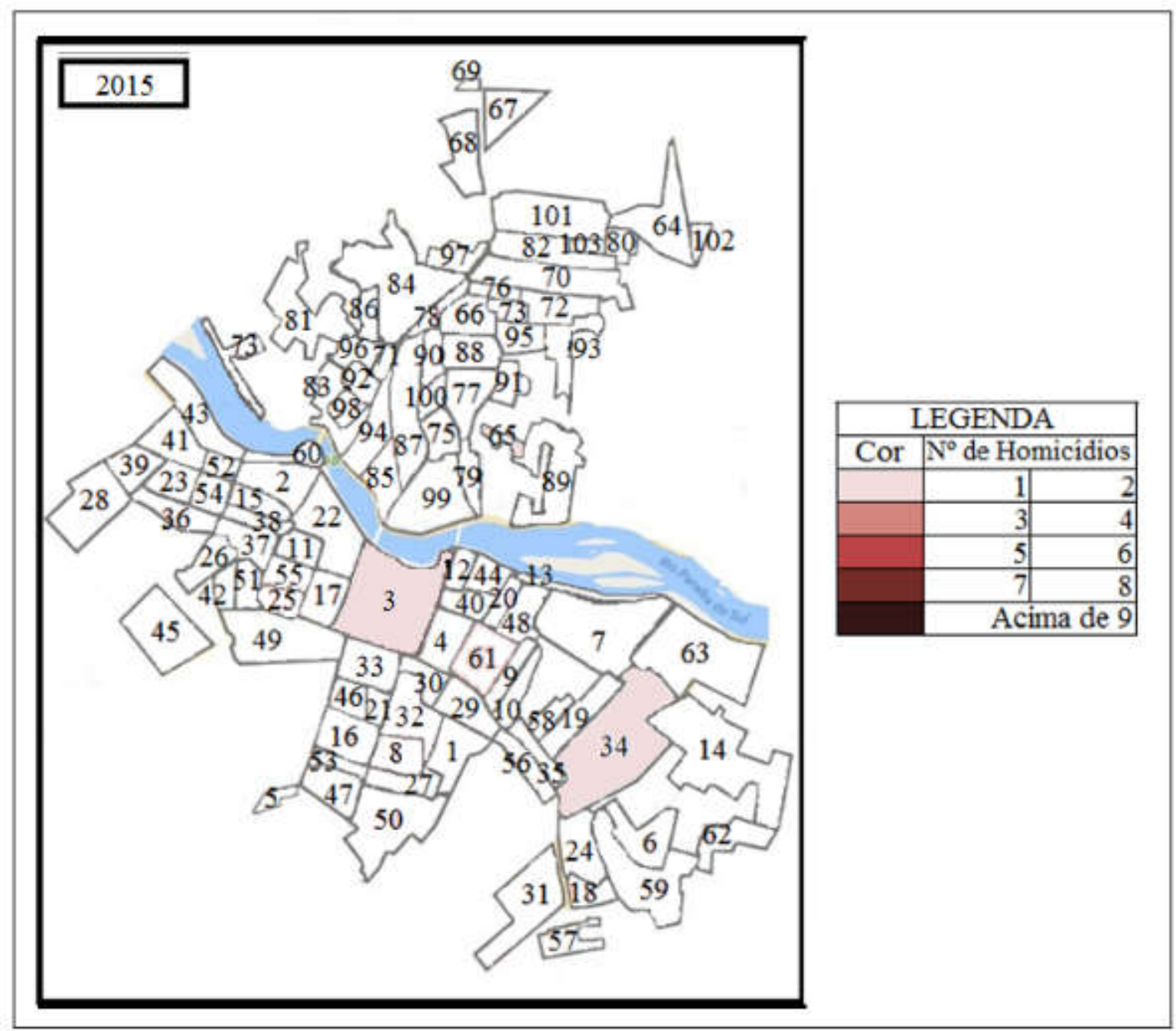

Fonte: Jornal O diário; Autora (2017)

Analisando os dados de estupros ocorridos, o Gráfico 4 mostra grande crescimento do número de ocorrências em ambas as áreas analisadas. A zona da $146^{\mathrm{a}}$ (Guarus) fica com as maiores ocorrências, mas não tem expressiva diferença entre ela e a área da $134^{\mathrm{a}}$. No ano de 2013 , porém, ocorre significativo crescimento de denúncias de estupros na $146^{a}$ DP. No ano seguinte, ocorre uma queda nas ocorrências, mas o número não chega a ser menor que o da outra região territorial.

O estupro, nos anos de análises, foi pouco representado na mídia impressa (Tabela 1). No ano de 2003, não tivemos nenhuma notícia. Em 2006, seis bairros são noticiados, quatro deles localizados no subdistrito Centro (Centro, Jockey Club, Chatuba e Nova Brasília) e dois em Guarus (Pq. Calabouço e São Silvestre), ou seja, uma notícia para cada bairro. Observa-se que nesse tipo de delito as áreas periféricas são mais representadas.

No ano de 2009, as ocorrências das notícias acontecem em dois bairros de Guarus e uma no subdistrito Centro. Em 2013, o bairro Imperial, localizado na periferia no subdistrito Centro, se destaca. 
Gráfico 4. Comparação das ocorrências de Estupros entre as unidades territoriais da $134^{a}$ DP e $146^{a}$ DP por 50.000 hab. (2003 a 2015).

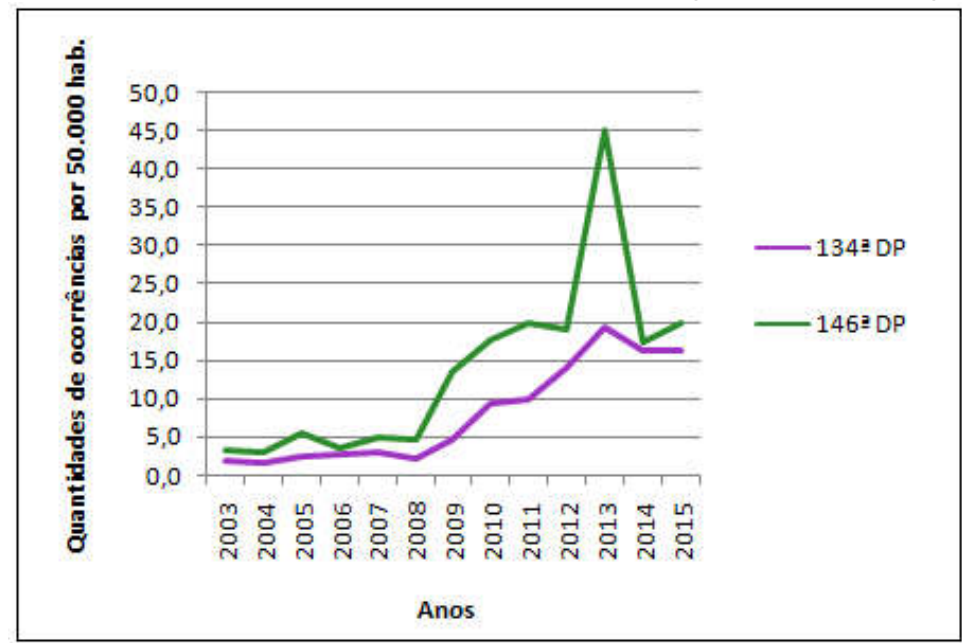

Fonte: Instituto de Segurança Pública; Elaboração da Autora.

Em 2015, novamente não há notícias de estupros ${ }^{13}$. Em uma visão geral, esse delito é pouco representado pela mídia, embora seja um crime que choca a sociedade. Percebemos certa cautela nas representações dessa violência. Essa não representação da mídia entra em contradição com os dados reais que apresentam crescimento significativo nos últimos anos, ou seja, a mídia tem ocultado esse crescimento ${ }^{14}$.

A análise de roubos a residências, embora pouco expressiva, foi necessária visto que a população de modo geral tem mudado sua forma de habitação por medo da violência criminosa. No senso comum, haveria muitos roubos às residências. A sensação de insegurança ocorre dentro de suas casas, ou seja, se sentem inseguros dentro delas. Então fizemos esta análise, pois esse delito está diretamente relacionado à falta de segurança dentro dos lares, já que o crime ocorre exatamente contra a residência. Sendo assim, podemos constatar que a própria mudança no tipo de habitação já é uma estratégia de proteção. O objetivo da pesquisa foi fazer uma análise não só quantitativa, mas também qualitativa entre os dois subdistritos Centro e Guarus, para refletir se Guarus seria inseguro e o Centro mais seguro. Nesse sentido, podemos observar variações constantes entre as duas áreas.

Ao analisar o Gráfico 5 , a princípio já percebemos que ocorrem poucos delitos desse tipo, o que é insuficiente para validar a insegurança dentro das casas. $O$ gráfico mostra que os valores são inferiores a sete no período analisado. Em 2003, a área da $134^{a} \mathrm{DP}$ começa com número superior ao da $146^{\mathrm{a}} \mathrm{DP}$. Nos próximos três anos (2004, 2005 e 2006), o subdistrito Guarus chega a 6, valor maior que o da outra área. De 2007 a 2013, o quadro muda, e o território da $134^{\mathrm{a}} \mathrm{DP}$ fica com números superiores. Em 2012, ocorre a elevação nos dados da $146^{a} \mathrm{DP}$, ficando superior nos anos de 2013 e 2014. Em 2015, ocorre queda nos números de ambas as DPs, ficando a $134^{\mathrm{a}} \mathrm{DP}$ com maior número.

\footnotetext{
13 Não apresentamos a cartografia dos bairros mais noticiados segundos os crimes de estupro e roubo a residência, pois foram poucas as ocorrências.

14 Várias hipóteses podem ser aventadas sobre essa constatação, como por exemplo, o fato da mídia ter como proprietários, em sua maioria homens, que, por sua vez, expressam o conteúdo de uma sociedade machista e sexista, sendo as mulheres as maiores vítimas desse crime, não seria prioridade esse tipo de notícia. Isso pode ser um indício, entretanto não aprofundaremos a questão neste artigo.
} 
Tabela 1. Ocorrência de Estupros entre as $134^{\circ}$ DP e $146^{\circ}$ DP de Campos dos Goytacazes no jornal O diário.

\begin{tabular}{|c|c|c|c|c|c|c|c|}
\hline \multirow[b]{3}{*}{ Ano } & \multicolumn{3}{|c|}{$134^{\circ} \mathrm{DP}$} & \multicolumn{4}{|c|}{$146^{\circ} \mathrm{DP}$} \\
\hline & \multicolumn{2}{|c|}{ Centro } & \multirow{2}{*}{$\begin{array}{c}\text { Demais } \\
\text { Localidades } \\
\text { Quantidade }\end{array}$} & \multicolumn{3}{|c|}{ Guarus } & $\begin{array}{c}\text { Demais } \\
\text { Localidades }\end{array}$ \\
\hline & Quantidade & Capa & & Quantidade & Capa & Especificado & Quantidade \\
\hline 2003 & e & $\theta$ & $\theta$ & Q & $\theta$ & Q & e \\
\hline 2004 & $Q$ & Q & 2 & Q & Q & $Q$ & Q \\
\hline 2005 & Q & Q & Q & 7 & 3. & 3 & 1 \\
\hline 2006 & 4 & 2 & $\bar{Q}$ & 2 & Q & 1 & Q \\
\hline 2007 & Q & Q & 1 & 6 & 1 & 5 & 1 \\
\hline 2008 & Q & Q & Q & 5 & Q & 2 & Q \\
\hline 2009 & 1 & $\bar{Q}$ & Q & 2 & 1 & 0 & 1 \\
\hline 2010 & 2 & Q & 2 & 3 & Q & 1 & 3 \\
\hline $2011^{8}$ & Q & $\bar{Q}$ & Q & 1 & Q & 1 & $Q$ \\
\hline $2012^{8}$ & $\theta$ & Q & 4 & 2 & d & 1 & e \\
\hline 2013 & 4 & Q & 1 & 1 & Q & 0 & Q \\
\hline 2014 & 5 & Q & 1 & 2 & 1 & 0 & 1 \\
\hline 2015 & Q & Q & Q & Q & Q & $\theta$ & 1 \\
\hline
\end{tabular}

Fonte: Jornal O diário; Autora (2017)

Os dados mostram que esse delito não é tão discrepante entre os territórios das duas DPs em Campos. A população residente no subdistrito Centro, porém, tem mudado a sua forma de habitação mais intensamente. É no Centro onde podemos verificar o intenso surgimento de residenciais fechados. Esse processo em Guarus começou tímido, se comparado ao do outro subdistrito. $O$ roubo a residência acontece mais frequentemente em bairros de classes de alto poder aquisitivo.

Gráfico 5. Comparação das ocorrências de Roubo a residência entre as unidades territoriais da $134^{\mathrm{a}}$ DP e $146^{\mathrm{a}}$ DP por 50.000 hab. (2003 a 2015).

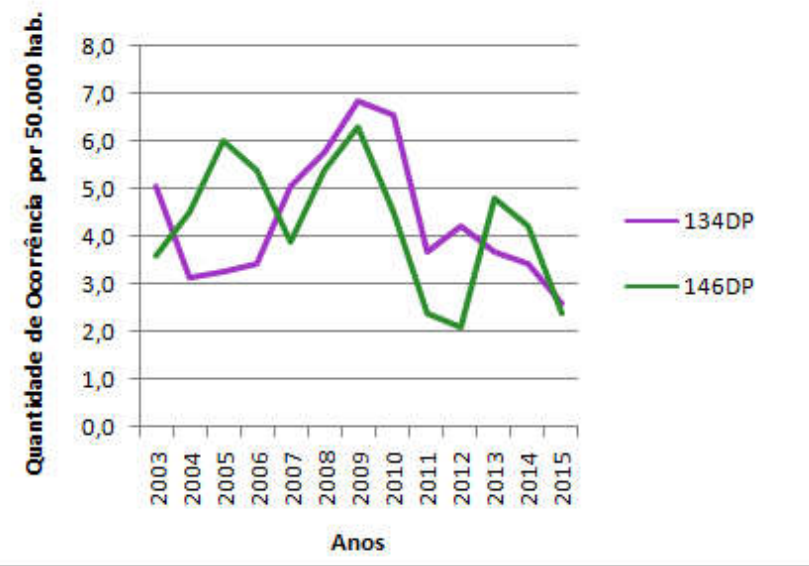

Fonte: Instituto de Segurança Pública; Elaboração da Autora. 
Podemos observar que, em alguns anos, há mais casos na mídia do que o registrado em dados reais (Tabela 2). Isso ocorre porque as pessoas tendem, muitas vezes, a evitar fazer registro de ocorrência.

Tabela 2. Roubo a residência entre as $134^{\circ} \mathrm{DP}$ e $146^{\circ} \mathrm{DP}$ de Campos dos Goytacazes no jornal O diário.

\begin{tabular}{|c|c|c|c|c|c|c|c|}
\hline \multirow{3}{*}{ Ano } & \multicolumn{3}{|c|}{$134^{\circ} \mathrm{DP}$} & \multicolumn{4}{|c|}{$146^{\circ} \mathrm{DP}$} \\
\hline & \multicolumn{2}{|c|}{ Centro } & \multirow{2}{*}{$\begin{array}{c}\text { Demais } \\
\text { Localidades } \\
\text { Quantidade }\end{array}$} & \multicolumn{3}{|c|}{ Guarus } & \multirow{2}{*}{$\begin{array}{c}\text { Demais } \\
\text { Localidades } \\
\text { Quantidade }\end{array}$} \\
\hline & Quantidade & Capa & & Quantidade & Capa & Especificado & \\
\hline 2003 & 9 & 2 & 4 & 3. & Q & 2. & Q \\
\hline 2004 & 16 & 1 & 2. & 4. & e & 2. & 1 \\
\hline 2005 & 5. & 2. & 2 & 1. & e. & 0 & e \\
\hline 2006 & $z$ & Q & 2. & 4 & e. & 2 & 1. \\
\hline 2007 & 6 & 1. & 3. & 2. & 0 & 2. & e \\
\hline 2008 & 4. & e & 1 & e. & e & e. & 3. \\
\hline 2009 & 12 & 2. & 1. & 6 & 2. & 3. & 4. \\
\hline 2010 & 7 & Q & e. & 1 & e. & 0 & 4. \\
\hline $2011^{*}$ & 1 & Q & Q & Q & Q & Q & Q \\
\hline $2012^{*}$ & 3. & 1. & 1. & 2 & e & 1. & e \\
\hline 2013 & 5. & 2. & 1. & 2. & Q & Q & e. \\
\hline 2014 & 10 & 2 & 2. & 3. & Q & 1 & Q \\
\hline 2015 & 1 & e. & 1 & Q & Q & Q & 0 \\
\hline
\end{tabular}

Fonte: Jornal O diário; Autora (2017)

O bairro Centro fica em mais evidencia durante o período de análise, porém a população de alto poder aquisitivo não ocupa esses espaços, ela se localiza mais a Oeste, área que foi pouco representada. Em 2006, as menções aumentam, porém são representados somente casos ocorridos na periferia.

Em 2009 e 2013, podemos analisar que, embora pouco representados no geral, os bairros de médio e alto poder aquisitivo aparecem mais, dentre eles são: Parque Dom Bosco, São Caetano e Tamandaré. Em 2015, esse delito é pouco representado, as únicas ocorrências que aparecem são as dos bairros Centro e Jockey Club.

A violência criminosa no município de Campos é notória e, por vezes, chega a ser superior, em proporções, ao estado e à sua capital. Os crimes violentos não são homogêneos no espaço. Nas áreas do subdistrito Centro, há maiores ocorrências de delitos contra o patrimônio e, nas áreas do subdistrito Guarus, contra a vida. O espaço impõe-se como um elemento de sujeição à violência, pois a depender de onde se more, pode-se estar mais ou menos sujeito aos diferentes tipos de violência.

Como podemos verificar, a mídia distorce a realidade com estratégias às vezes contraditórias. Fica evidente que ela oculta os crimes que ocorrem mais em áreas nobres, ou seja, no subdistrito Centro, ao passo que Guarus é superexposto.

O crescimento da violência criminosa em Campos dos Goytacazes no período analisado, aliado à intensa propagação midiática sobre os crimes ocorridos em 
lugares seletivamente enfatizados, tem gerado intensa sensação de medo na população. Essa insegurança em relação ao outro proporcionou várias estratégias materiais e simbólicas que operam de forma a estabelecer diferenças, divisões, exclusão e restrição de fluxos da população residente do Centro para Guarus. Essas estratégias são denominadas no estudo de Caldeira (2011, p. 28) como "evitação".

Caldeira (2011, p. 10) esclarece que a fala do crime reordena simbolicamente o mundo quando elabora preconceitos e naturaliza a percepção de alguns grupos como perigosos. O caso de Campos dos Goytacazes se assemelha a esse processo de reordenação simbólica quando os residentes da área do Centro naturalizaram a ideia de perigo ao se referirem à população que mora em Guarus.

Essa criminalização simbólica em Campos é um processo social tão difundido e dominante que tem refletido na localização dos condomínios residenciais fechados, com "evitação" do subdistrito de Guarus. Apesar desse modo de habitação ser marcado pela localização em periferias, não é em qualquer periferia que esses condomínios têm se estabelecido.

A autossegregação dessas classes tem como uma de suas justificativas o aumento da violência. A recusa e a falta de interesse por habitações na área de Guarus expõem um medo tão excessivo, que gera grande resistência a residir na localidade mesmo sendo rodeado por uma muralha, que é uma das características dos residenciais fechados.

\section{CONSIDERAÇÕES FINAIS}

A violência, como vimos, é polissêmica. Neste trabalho destacamos a violência criminosa para análise da segregação residencial em Campos dos Goytacazes. A violência criminosa tratada neste artigo diz respeito a ocorrências de delitos destacados no Instituto de Segurança Pública: homicídios, roubos a transeuntes, roubo a residência e estupro. Os delitos selecionados têm a prática reprimida pelo Estado e sociedade e são representados nos jornais $O$ Diário e $A$ Folha da Manhã com certa frequência.

No processo histórico da formação do espaço urbano do município de Campos dos Goytacazes, podemos ponderar que o Estado, na escala municipal, auxiliou no processo de consolidação da segregação contra os pobres marginalizados ao privilegiar as áreas das classes de alto poder aquisitiva quanto às aplicações de infraestrutura e intervenções urbanísticas. Isso resultou em áreas com menos estruturas, que atualmente ainda o são, fazendo perdurar o medo e a insegurança das classes mais abastadas em relação aos pobres.

A insegurança em relação às classes menos abastadas ganha contornos específicos desde o século XX. A mídia tem e teve papel fundamental na propagação da sensação de medo, com a alimentação e a reprodução de discursos geradores de preconceitos e violência simbólica.

A partir da década da década de 1980, podemos verificar a complexificação do padrão Centro e Periferia, quando começaram a surgir os condomínios fechados de alto padrão nas áreas periurbanas do Centro, loteamentos irregulares nas áreas próximas ao Centro e a consolidação do processo de verticalização, sobretudo nas áreas mais valorizadas da cidade, evidenciando a fragmentação do espaço urbano. O processo de verticalização se intensificou a partir dos anos 2006/2007 na área central, em alguns bairros a Oeste do Centro, como Dom Bosco, Parque Tamandaré, Parque Avenida Pelinca, Parque Jardim Maria de Queiroz, Parque Conselheiro Tomaz Coelho e Jardim Flamboyant. Com infraestrutura melhor 
equipada, são áreas que continuam sendo privilegiadas pelas intervenções do poder público e valorizadas pela iniciativa privada (FREITAS, 2011, p. 69). Já nas áreas periféricas, estão localizados os edifícios com pouca estrutura e com preços mais acessíveis (FREITAS, 2011, p.125).

Em meio ao contexto da verticalização, surge uma nova tipologia habitacional: os condomínios horizontais fechados. Em um período mais recente, isso provocou deslocamentos para as áreas periféricas, que apresentam a segurança e a exclusividade como diferenciais. Esses padrões residências coexistem, mantendo a diversificação do mercado, o que garante atendimento às diferentes preferências de uma mesma camada social (ZACCHI, 2012, p. 85).

A concentração de condomínios no espaço periurbano gera proximidade física entre as distintas classes, mas distanciamento nas interações. Essa nova forma de habitação tem mudado o padrão de segregação espacial, as interações entre as classes, bem como o caráter do espaço público (ZACCHI, 2012, p. 138). Os muros dos condomínios representam uma barreira física, simbólica e social. Eles concretizam a separação socioespacial, rompem com a totalidade do espaço urbano, atenuam as relações entre os habitantes e a cidade e fragmentam o modelo centro e periferia (ZACCHI, 2012, p. 158).

A análise da violência criminosa em Campos dos Goytacazes considerando os crimes de homicídio, de estupro, e os roubos a transeunte e a residência - revela que os crimes que são mais recorrentes são os homicídios e roubo a transeunte. O homicídio e o estupro ocorrem mais na área da $146^{\circ} \mathrm{DP}$, ao passo que os roubos a transeunte e a residência ocorrem mais na área da $134^{\circ} \mathrm{DP}$. Segundo a pesquisa realizada, a frequência de mortes ocorridas na região de Guarus está ligada ao tráfico de drogas. As facções não têm seu território consolidado, causando nesses embates os expressivos números de mortes. $\mathrm{Na}$ área periférica do subdistrito Centro, tem surgido intenso número de residenciais fechados que têm a segurança como um dos discursos de marketing de venda. Os dados de roubo a residência, contudo, são pouco expressivos para justificar a mudança no modo de habitação.

A violência criminosa na cidade de Campos é notória. Podemos perceber tal fato a partir dos dados do Instituto de Segurança Pública sobre os quatro delitos selecionados. Ela não se encontra, porém, concentrada totalmente no subdistrito Guarus e nem o contrário é verdade; ou seja, ela não é homogênea no espaço, tão pouco tem as mesmas intensidades nos diferentes tipos de delitos. O que tem ocorrido é a generalização em relação a Guarus, trabalhada pela mídia todos os dias, quando anuncia crimes ocorridos em bairros especificando o subdistrito Guarus. As representações da mídia sobre a violência já se caracterizam como uma violência contra a comunidade, ou seja, a violência da representação.

A população de Guarus é triplamente penalizada: pelas políticas públicas, que se concentram nas áreas nobres, especialmente no primeiro subdistrito Centro; por ser a maior vítima da violência - homicídios e estupros são maiores nesta área -; e pela estigmatização propagada pela mídia, o que torna Guarus vítima de uma violência simbólica, que gera desdobramentos materiais e imateriais na vida da população residente nessa área.

As altas taxas de homicídios em Campos dos Goytacazes, sobretudo nas representações da mídia, têm gerado maior sensação de insegurança na população. Essa insegurança faz com que a população assuma diversas formas de estratégias de proteção para se sentirem seguras, e a reclusão em residenciais fechados tem sido uma opção recorrente para as classes sociais de média e alta rendas. Esse fato 
tem modificado o espaço urbano da cidade em tela, com o aumento significativo dos residenciais fechados concentrando-se principalmente no subdistrito Centro.

Esse modelo de habitação, denominada residencial fechado horizontal, tem no muro uma forma de separação entre as classes na concretude material. Além disso, tem sua localização em áreas periféricas do subdistrito Centro, buscando isolamento e autossegregação.

Mesmo com uma concretude material de separação, a população de alto poder aquisitivo tem dispensado a ideia de residir no subdistrito Guarus, processo causado pela combinação da violência real - que ocorre em determinados bairros de Guarus - e a difusão pela mídia de Guarus como uma região muito violenta. Em outras palavras, a espacialização dos residenciais fechados, sobretudo horizontais, que tem como característica a localização em áreas periféricas, é resultado de uma combinação de elementos: a segregação gerada pelo tratamento desigual do Estado nos investimentos públicos; os altos índices de ocorrências de delitos, sobretudo homicídios em determinado bairros em Guarus decorrentes das disputas de território entre as facções; e o tratamento da mídia às ocorrências de crimes violentos.

A pesquisa revelou que o espaço urbano não é homogêneo do ponto de vista da violência real. Há crimes mais frequentes em determinados bairros, como os homicídios e os estupros. A mídia, entretanto, é enfática tanto em noticiar alguns tipos de crimes quanto em determinar os lugares eleitos para serem os mais violentos, mesmo que não o sejam. Ela relata tanto a violência criminosa, que passa a parecer um fator habitual. Por se tornar corriqueira e difusa, parece natural dos espaços públicos, ou seja, torna-se justificável ficar recluso em habitações com o máximo de segurança. A visão da mídia acaba impregnada no quotidiano da cidade, é um elemento componente da segregação socioespacial da cidade.

\section{REFERÊNCIAS}

\section{Autora, 2017}

CALDEIRA, T. P. do R. Cidades de muros: Crime, segregação e cidadania em São Paulo. 2. ed. São Paulo: Edusp, 2011.

CORREAA, Roberto Lobato. Segregação residencial: classes sociais e espaço urbano. In: Vasconcelos, Pedro de Almeida; Corrêa, Roberto Lobato; Pintaudi, Silvana Maria. A cidade contemporânea: segregação espacial. São Paulo: Contexto, 2013.

CORREAA, Roberto Lobato. O espaço urbano. São Paulo: Ática, 2005.

FARIA, Teresa Peixoto. Configuração do espaço urbano da cidade de Campos dos Goytacazes, após 1950: novas centralidades, velhas estruturas. Anais do X Encontro de Geógrafos da América Latina - 20 a 26 de março de 2005 Universidade de São Paulo, São Paulo, 2005. p. 4778-4799.

FARIA, T.P; VIEIRA, S.P. Princípios de legislação urbanística, planejamento urbano e divisão do espaço: Um estudo do Plano de Desenvolvimento Físico-Territorial Urbano de Campos dos Goytavazes/RJ. In. CONGRESSO BRASILEIRO DE SOCIOLOGIA, 11., 2003. UNICAMP. Anais... Campinas, 2003, p. 1-20.

FREITAS, Kêila P. da Silva. Produção e apropriação do espaço urbano de Campos dos Goytacazes - RJ: da residência unifamiliar aos edifícios de apartamentos. [Mestrado em Políticas Sociais]. Campos dos Goytacazes: Universidade Estadual do Norte Fluminense Darcy Ribeiro, 2011. p. 1-150.

GOMES; M. A. S. A produção e a valorização desigual do espaço urbano em Campos dos Goytacazes-rj: uma análise das ações do estado e dos 
promotores/incorporadores imobiliários. Geografares, Espirito Santo. n. 19, p. 28-41, jan./jul. 2015.

Jornal Folha da Manhã. Campos dos Goytacazes, 2003-2015. p 1-10

Jornal O Diário. Campos dos Goytacazes, 2003-2015. p. 1-10

PIQUET, Rosélia; SERRA, Rodrigo. Petróleo e Região no Brasil: o desafio da abundância. Rio de Janeiro: Garamond, 2007.

SPOSITO, Maria E. Beltrão; GOÉS, Eda Maria. Espaços Fechados e Cidades: Insegurança Urbana e Fragmentação Socioespacial. São Paulo, ed. Unesp, 2013.

VILLAÇA, F. Espaço intra-urbano no Brasil. 2a ed. São Paulo: Studio Nobel: Fapesp: Lincoln Institute, 2001.

ZACCHI, R.C. O papel dos proprietários e do Estado no processo de conversão de terras rurais em urbanas e na produção de loteamentos fechados: Campos dos Goytacazes (1980-2001). [Mestrado em Políticas Sociais]. Campos dos Goytacazes: Universidade Estadual do Norte Fluminense Darcy Ribeiro, 2012. 